\title{
HUMAN SETTLEMENTS AND THE LAST DEGLACIATION IN THE FRENCH ALPS ${ }^{1}$
}

\author{
JACQUES EVIN, ${ }^{2}$ PIERRE BINTZ ${ }^{3}$ and GUY MONJUVENT ${ }^{4}$
}

\begin{abstract}
According to most geological and geomorphological studies, the maximal advance of the Würmian glaciers in the French Alps occurred at least before $40 \mathrm{ka} \mathrm{BP}$ and cannot be dated by ${ }^{14} \mathrm{C}$. Scientists believed that this dating method could be used for dating the last glacial advance and late deglaciation in the region. The scarce and scattered ${ }^{14} \mathrm{C}$ dating results available from geological samples do not confirm an early ( $c a .18$ or $20 \mathrm{ka} \mathrm{BP}$ ) age for the total cooling of the ice nor do they prove that residual ice sheets remained at low elevations. Attempting to solve this chronological problem, we compiled current archaeological knowledge of the oldest Late Paleolithic sites. A review of their ${ }^{14} \mathrm{C}$ results shows that no site older than $15 \mathrm{ka}$ BP (with Gravettian, Solutrean or early Magdalenian industries) can be found east of the Saône-Rhône Valley, even at low elevations. Only rare sites, dated to $c a .14 .5 \mathrm{ka} \mathrm{BP}$, may be found close to the mountain regions that were suddenly occupied around the beginning of the Bølling period (ca. $13.5 \mathrm{ka} \mathrm{BP}$ ). Thus, it seems that the eastern Alps offer no evidence for direct association between glacial retreat and human settlement or simultaneous occurrence in early or late deglaciated areas.
\end{abstract}

\section{INTRODUCTION}

Each year, many new Middle and Upper Paleolithic archaeological sites are discovered in Europe. We could infer from this that Homo sapiens wanted to occupy all the available terrain across much of the European land mass, and was limited or driven back only by the developing inland ice sheets of Northern Europe. To test this hypothesis, we decided to study the distribution of human settlements linked with the retreat of the glaciers. A quasi-contemporaneity between glacial retreat and new settlements would confirm the likelihood that Homo sapiens branched out to every possible location; on the other hand, a delay in the occupation of vacant areas would suggest that factors other than deglaciation may have governed the distribution of settlements.

Conclusions related to widespread human settlement have often been reached for central and eastern Europe in relation to the expansion and recession of the Scandinavian glaciers. To draw the same conclusions for the western European mountains, one must first consider the types of glaciers, the dates of their last retreats, as well as the sources of information. Only then would it be possible to assess the known Paleolithic sites and to evaluate their distance from the corresponding glacial front.

\section{GLACIAL HISTORY OF THE FRENCH ALPS}

The French Alps are made up of a central mountain massif with high summits (ca. 4000-m elevation) surrounded by several smaller massifs at lower elevations $(c a .2000 \mathrm{~m}$ ), and huge piedmont plains, cut by deep valleys. Because of these contrasting landscapes, the accumulated ice encircled the higher peaks, covered the high plateaus with glacial ice caps and spread long ice sheets over mountain valleys and their extensions.

The shape of the glacial structures of the Alpine massif, often simplified into an ellipse with linear outlines, comparable to the glaciers of Northern Europe or North America, is, in fact much more complex. The ice spread far into the peripheral massifs and into the valleys or onto the plains. Thus, the front of the last major glacial advance of the Würmian can be characterized as an extremely sin-

\footnotetext{
${ }^{1}$ This paper was presented at the Archaeology Workshop, 15 th International ${ }^{14} \mathrm{C}$ Conference, 14 August 1994, Glasgow, Scotland. ${ }^{2}$ Laboratoire de Radiocarbone, Université Claude-Bernard - Lyon I, 43, Boulevard du 11 Novembre, F-69622 Villeurbanne, France

${ }^{3}$ Département de Préhistoire et Quaternaire, Institut Dolomieu, Université de Grenoble, 15, Rue Maurice-Gignoux, F-38031 Grenoble, France

${ }^{4}$ Laboratoire de la Montagne Alpine, Institut Dolomieu, Université de Grenoble
} 
uous line (Fig. 1). To reconstruct this complex scenario, we must make a systematic investigation of the surface evidence. The highly varied topography, differential glacial melting, catchment basins formed to collect the downslope water flow and ice masses accumulated at the bottom of the deeply carved valleys all indicate that glacial movements were complex throughout the region, and may have varied from north to south, and from one valley to another.

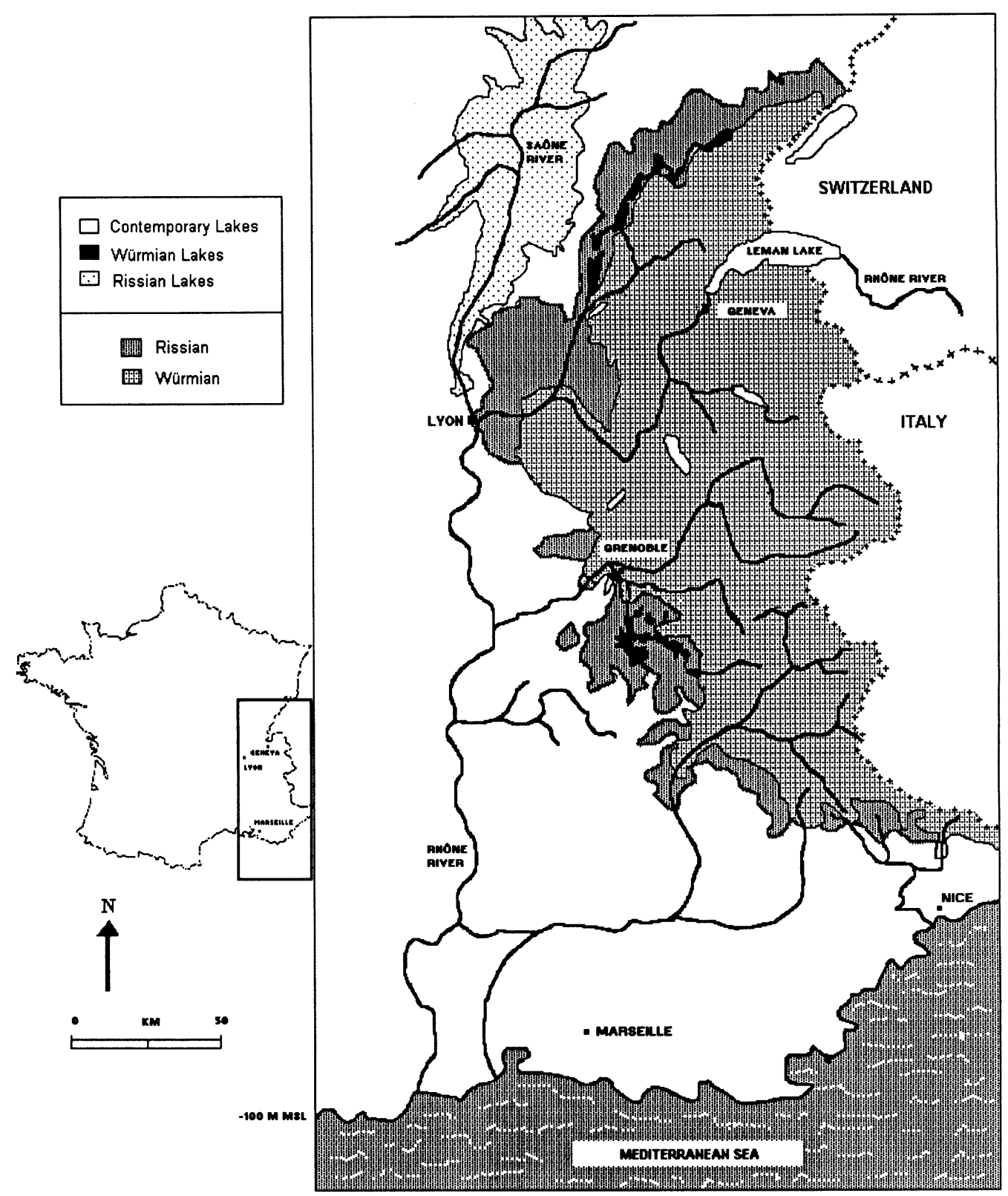

Fig. 1. Maximum of glacial front of the last glaciation in the French Alps 
Global climate change influenced Alpine glaciers, with many more fluctuations than boreal ice caps, as their relatively low mass must have rendered them vulnerable to small climate variations. The relief and latitude of the massif affected the rhythm of glacial advances and retreats, which were unrelated to glacial events and behavior in other areas. Perhaps humidity also played a more significant role in the high massif than in lower elevations where precipitation is not blocked by high peaks. Thus, it is difficult to reconstruct the paleogeography of glacial movements and establish their chronology at the same time, both of which are crucial to understanding the process of the first human settlements after deglaciation. We must then turn to all the available geologic and archaeological data.

In the French Alps, the last (Würmian) glaciation was smaller than its predecessor (Rissian) (Mandier 1984; Monjuvent 1971). On the whole western arc, Rissian moraines extended farther than did Würmian moraines (Fig. 1), but neither the precise date of the Rissian maximum, nor the number of major advances and retreats during the Riss is known, despite numerous studies spanning more than a century (Mandier 1984). Figure 1 shows the different maxima of the Rissian and Würmian glaciations. The current landscape was shaped more by the Rissian glaciation than by the Würmian; its great curves are about the same as those of the Riss-Würm interglacial. With the similarity of landscapes, it is not surprising, then, that Middle Paleolithic sites, whose dates are older than the Würmian glaciers, are found where late Magdalenian sites were settled some $80 \mathrm{ka}$ later.

During the Würmian, the earlier of two main glacial advances in the western French Alps, was the most extensive. Yet, in certain frontal regions, as in the vicinity of Lyon, for example, the difference between the two borders of terminal moraines is clearly visible, yet at slightly higher elevations, no difference can be seen between these two stages. Thus, some authors believe that only one long oscillating Würmian advance affected the piedmont area (Monjuvent and Nicoud 1988).

In recent years, much research has been done on the end of the last glacial retreat, in the middle Rhône River Valley and Lac Léman basin (Arn 1984; Mandier 1984; Monjuvent 1988). A rhythmic retreat through numerous stages of halting, abandonment of sheets of stagnant ice and formation of kame terraces and temporary lakes were noted (Fig. 2). The absolute date of the last retreat has not yet been established, but it seems to date from $c a$. 15-18 ka BP in the most meridional parts of the Alps (Jorda, Rosique and Evin 1980) or in the Jura massif (Campy and Richard 1988). Mandier $(1984,1988)$ argues for a recent age on the basis of the elevations of the fluvioglacial terraces of the central Isère and Rhône glaciers, and from ${ }^{14} \mathrm{C}$ dates from bones found in those terraces (Table 1).

\section{RADIOCARBON DATING THE GLACIAL RECORD}

Few possibilities exist for direct ${ }^{14} \mathrm{C}$ dating of glacial or fluvioglacial deposits. The presence of carbon in these landforms is extremely rare. Bones are always absent from moraines, as they are too fragile to withstand the crushing transport of glacial debris. All bone dates at $c a .25-40 \mathrm{ka}$ BP are from Ursidae in the karstic networks of Le Bugey, La Chartreuse or Le Vercors massifs (Table 1), but their relation to glaciation is uncertain. Charcoal has never been found, and the rare piece of wood that is found is totally unreliable, because it may have been redeposited by previous interglacial or interstadial activity.

\section{GEOLOGICAL DATING}

As direct dating of glacial landforms is impossible, we can date either the interstadial features underlying or adjacent to the moraines, or the fluvial terraces linked with the runoff outlets of the melting glaciers. Table 1 lists two series of dates. The first series, at $c a .25 \mathrm{ka}$ BP or older, were 


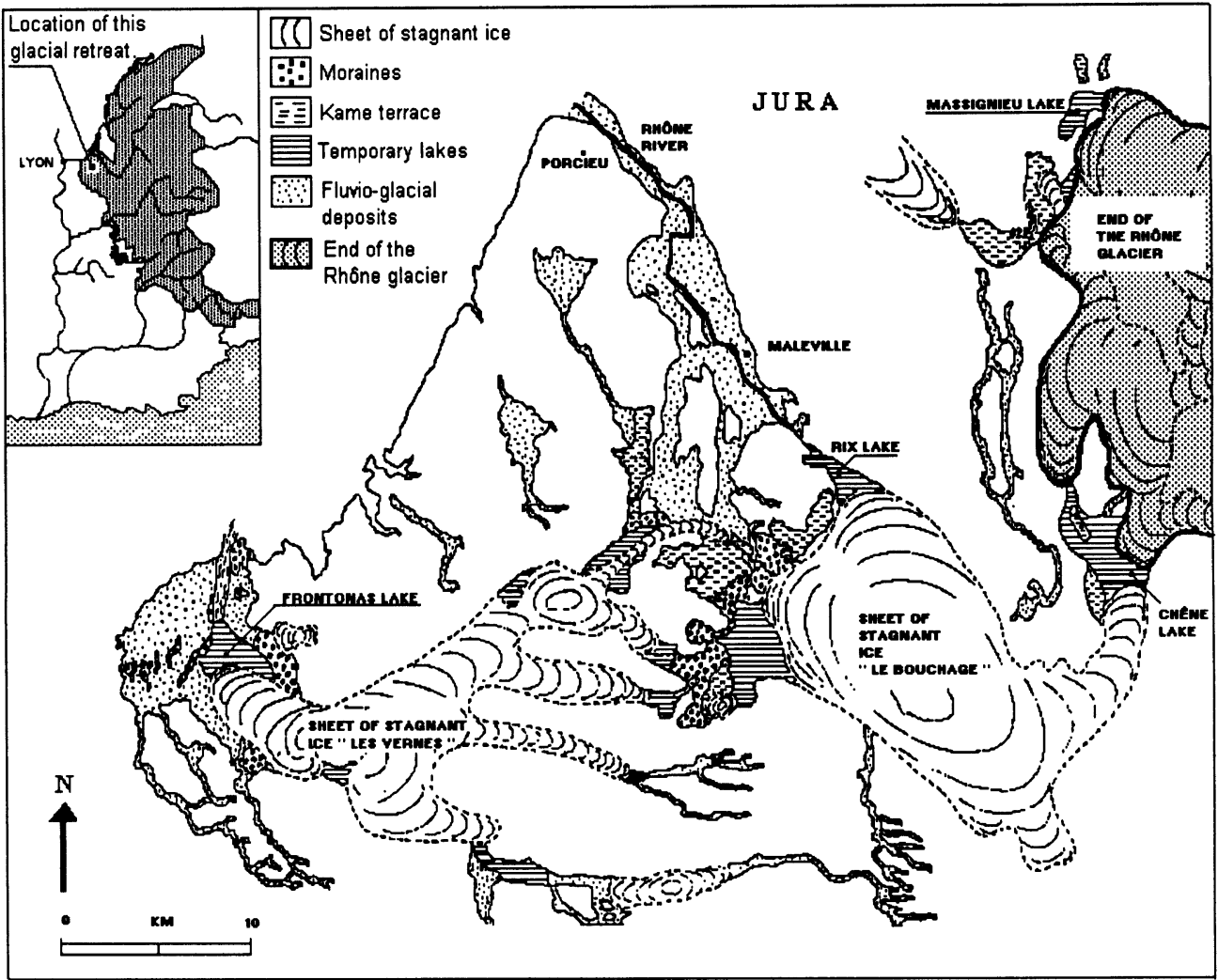

Fig. 2. One phase of the Rhône glacial retreat, showing that several sheets of stagnant ice and fluvioglacial deposits formed temporary lakes

obtained from peat sediments collected in the Chablais region in the Dranse Valley close to Lac Léman, which were associated with the Rhône glacier (Blavoux and Brun 1966). However, these dates cannot confirm, with absolute certainty, the oldest age of the last glacial advance. Another series of dates, between 25 and $17 \mathrm{ka}$ BP, at Pugneux close to Lyon, on peat deposits adjacent to the end moraine of the Würmian Rhône glacial maximum near Lyon (Evin, Marien and Pachiaudi 1976), disagrees with geological evidence placing the maximum earlier than 35 ka BP. Dates between 45 and $60 \mathrm{ka} \mathrm{BP}$ from an interstadial occupation underlying a glacial terrace in the region of Chambéry-Grenoble suggest that this Würmian maximum occurred ca. 40 ka BP (Hanss 1982). However, these dates are not reliable because the samples were probably contaminated, and some were measured with isotopic enrichment. One date (Ly-3814: 26,470 \pm 920$)$ on fragments of wood from a large lakeside terrace at the base of the Rhône River Valley, near Malville (Table 1), indicates a minimal age of several thousand years for the duration of the last retreat, but this can be a matter of redeposited material.

These dating results are contradictory. To date glacial or fluvioglacial landforms, there remains only ${ }^{14} \mathrm{C}$ dating of material uncovered in associated fluviatile terraces. Thus, we obtained a series of dates from low terrace basins of the Rhône River and from alluvial cones to the south of Lyon, on fluvioglacial material related to the last advance of the Rhône glacier. The dates range from 18 to $20 \mathrm{ka}$ BP (Table 1), and they derive from bones or other organic material contained in clays from the first 
stage of retreat (Grenay stage). The youngest date: Ly-4818: 14,090 \pm 120 BP from Montalieu-Porcieu probably relates to one of the last stages of Rhône glacial retreat (Morestel stage) (Fig. 2) (Mandier and Piegay 1991).

Obtaining a minimum for a terminal age of a glacial retreat can be achieved by dating paludal or lakeside terraces, for example, in the Lac Léman region. Dates from the Allerød period are of little

TABLE 1. Radiocarbon Dates from Geological Sites of the French Alps, Jura Massif and Saône-Rhône Valley from $40-11.5 \mathrm{ka}$

\begin{tabular}{|c|c|c|c|c|c|}
\hline Region & Lab no. & Site & Material & Layer/Level & $\begin{array}{l}{ }^{14} \mathrm{C} \text { age } \\
\text { (yr BP) }\end{array}$ \\
\hline Bugey & Ly-4166 & Grotte du Pissoire & Bone & Layer 1 & $24,360 \pm 530$ \\
\hline Bugey & Ly -4165 & Grotte du Pissoire & Bone & Layer 4 & $31,000 \pm 1000$ \\
\hline Bugey & 7 Ly dates & Lac de Cerin & Peat & Boring from & $10,500 \pm 180$ to \\
\hline & & & & $691-1048 \mathrm{~cm}$ & $13,680+720$ \\
\hline Bas Dauphiné & Ly -4184 & Montalieu-Porcieu & Bone & Terrace & $14,090 \pm 120$ \\
\hline Bas Dauphiné & Ly-3814 & Malville & Wood & Boring $-20 \mathrm{~m}$ & $26,470 \pm 920$ \\
\hline Bas Dauphiné & 7 Ly dates & Le Grand Lemps & Peat & Boring from & $12,150 \pm 150$ to \\
\hline Chablais & 4 Gif dates & $\begin{array}{l}\text { (Clerc 1988) } \\
\text { Sionnex (Delibrias }\end{array}$ & Peat & $\begin{array}{l}4.7-15.1 \mathrm{~m} \\
\text { Boring from }\end{array}$ & $\begin{array}{l}14,670 \pm 180 \\
23,500 \pm 1200 \text { to }\end{array}$ \\
\hline & & et al. 1969 & & $31-187 \mathrm{~m}$ & $26,200 \pm 1200$ \\
\hline Chablais & Lu-1723 & Abri du Salève & Charcoal & Paleosol & $13,000 \pm 100$ \\
\hline Chablais & ETH-4532 & Grotte du Barée & Bone & Unknown & $38,470 \pm 810$ \\
\hline Chablais & Ly-2530 & Armoy & Peat & Fluviatile sediment & $\geq 35,000$ \\
\hline Chartreuse & Ly-5373 & Balme à Colomb & Bone & Boring & 233,000 \\
\hline Chartreuse & $\begin{array}{l}\text { Ly-3 / } \\
\text { OxA-3946 }\end{array}$ & Balme à Colomb & Bone & Square W4 & $24,160 \pm 370$ \\
\hline Chartreuse & Ly-3315 & Trou du Glaz & Bone & Single layer & $24,300 \pm 600$ \\
\hline Vercors & Ly-167 & Prélétang & Bone & Layer 9 & 232,000 \\
\hline Vercors & Ly-2811 & Balme Rousse & Bone & Base of filling & $26,000 \pm 1500$ \\
\hline Oisans & Ly-1647 & Chonas & Wood & Middle terrace & $11,530 \pm 260$ \\
\hline Oisans & Ly-2146 & Les 2 Alpes-Côtes Brune & Peat & Summit & $12,310 \pm 150$ \\
\hline Oisans & Ly-2147 & Les 2 Alpes-Côtes Brune & Peat & Base & $12,890 \pm 180$ \\
\hline Oisans & Ly-2401 & La Muzelle Il & Clay & Boring $-5.4 \mathrm{~m}$ & $13,460 \pm 390$ \\
\hline Royans & Ly-2621 & St. Hilaire du Rozier & Peat & $-2 m$ & $13,980 \pm 250$ \\
\hline Royans & Ly-2622 & St. Hilaire du Rozier & Clay & $-3.7 \mathrm{~m}$ & $15,200 \pm 250$ \\
\hline Royans & Ly-5014 & St. Hilaire du Rozier & Clay & $-13 m$ & $22,000 \pm 350$ \\
\hline Royans & Ly-5197 & St. Hilaire du Rozier & Clay & Base & $30,000 \pm 500$ \\
\hline Royans & Ly -3208 & St. Julien de Ratz & Peat & $-680 \mathrm{~cm}$ & $13,100 \pm 400$ \\
\hline Royans & Ly-3210 & St. Julien de Ratz & Peat & $-710 m$ & $12,580 \pm 540$ \\
\hline Royans & Ly-2983 & St. Julien de Ratz & Peat & $-725 \mathrm{~cm}$ & $12,470 \pm 320$ \\
\hline Lyonnais & 18 Ly dates & $\begin{array}{l}\text { Les Echets } \\
\text { (Evin et al. } 1985\end{array}$ & $\begin{array}{l}\text { Lacustrine } \\
\text { sediment }\end{array}$ & Boring from 4-24 m & $\begin{array}{l}11,910 \pm 350 \text { to } \\
24,500 \pm 500\end{array}$ \\
\hline Lyonnais & 5 Ly dates & $\begin{array}{l}\text { Pugneux } \\
\text { (Evin et al. } 1985\end{array}$ & Plant debris & Fluviatile sediment & $\begin{array}{l}17,300 \pm 510 \text { to } \\
24,110 \pm 900\end{array}$ \\
\hline Lyonnais & Ly-723 & Chasse sur Rhône & Bone & Top terrace & $12,120 \pm 180$ \\
\hline Lyonnais & Ly-653 & Chasse sur Rhône & Bone & Basal terrace & $14,350 \pm 290$ \\
\hline Lyonnais & Ly-360 & Saint Maurice l'Exil & Bone & Middle terrace & $18,800 \pm 490$ \\
\hline Valentinois & Ly-4458 & Cône Drôme River & Clay & Boring $-8.6 \mathrm{~m}$ & $11,850 \pm 400$ \\
\hline Valentinois & Ly-5529 & Cône Roubion River & Clay & Boring base & $15,550 \pm 260$ \\
\hline Valentinois & Ly-1689 & Salaise sur Sanne & Bone & Boring $-16 \mathrm{~m}$ & $14,110 \pm 620$ \\
\hline Valentinois & Ly-1690 & Salaise sur Sanne & Bone & Boring $-17 \mathrm{~m}$ & $20,370 \pm 460$ \\
\hline Provence & Ly-6388 & La Peyrerie & Wood & Fluvioglacial sediment & $18,600 \pm 200$ \\
\hline Provence & Ly- 6387 & La Peyrerie & Wood & Fluvioglacial sediment & $17,680 \pm 130$ \\
\hline
\end{tabular}


interest, because they are largely younger than the last ice retreat. Thus, despite much research over a 30-yr period, the date of the last glacial retreat in the French Alps remains inaccurate, based only on geological data.

\section{Archaeological Dating}

The rare carbon samples directly linked to glacial formations are most often archaeological remains, which can provide the most precise age information. Lithic artifacts are a stable material, and are important for dating, even if typological dating is often inaccurate. Archaeological sites from the plain are often covered with thick Holocene deposits. In the mountains, rock shelters almost exclusively provide either bone or charcoal samples for dating. Such samples are important, for, generally, they are not subject to major disturbances, and thus, to dating uncertainties arising from redeposited material. Consequently, archaeological material usually offers better guarantees for successful ${ }^{14} \mathrm{C}$ dating than does geological material.

\section{Archaeological Sites in the French Alps}

We are aware of $c a .100$ sites in the French Alps, the Jura Massif and the Saône-Rhône Valley for the Tardiglacial; 31 of them have been ${ }^{14} \mathrm{C}$-dated (Table 2). The geographical distribution is erratic (Fig. 3). Numerous sites are located in the Saône-Rhône Valley and along the margins of the smaller peripheral mountain massifs (Chartreuse, Vercors, Bugey) adjacent to areas of major erosional tracks such as where the Rhône and Isère River Valleys fan out. A few sites are in the interior of the massifs at medium elevation, but there are no sites in the central massifs and only a few in the south. It is always possible that the absence of sites is due more to lack of knowledge than to lack of settlements; however, the disparity between the west and east of the chain is, in itself, significant. Figure 3 shows that most sites are located in the west, particularly in the southwest, of the Saône and Rhône River Valleys.

TABLE 2. Radiocarbon Dates from Archaeological Sites of the French Alps, Jura Massif and SaôneRhône Valleys from 25,000-10,500 BP

\begin{tabular}{llllll}
\hline & & & & 14 C age & \\
Lab no. & Material & Site (no. in Fig. 3) & Layer / Level & (yr BP) & Culture \\
\hline Ly-2161 & Bone & Arcis sur Cure (1) & Layer V & $20,150 \pm 500$ & Gravettian \\
BM-1819 & Burned bone & Arcis sur Cure (1) & Layer V & $22,550 \pm 350$ & Gravettian \\
Ly-894 & Bone & Crest (2) & Single level & $12,850 \pm 240$ & Magdalenian \\
Ly-314 & Burned bone & Solutré (3) & Layer L13 & $16,440 \pm 300$ & Solutrean \\
Ly-316 & Bone & Solutré (3) & Layer L13 & $17,350 \pm 300$ & Solutrean \\
Ly-317 & Bone & Solutré (3) & Boring C & $24,050 \pm 600$ & Perigordian \\
Ly-312 & Bone & Solutré (3) & Boring B, Level 6 & $28,650 \pm 1100$ & Perigordian \\
Ly-313 & Bone & Solutré (3) & Boring B, Level 6 & $22,650 \pm 500$ & Perigordian \\
Ly-392 & Charred bone & Solutré (3) & Level P16 & $13,350 \pm 350$ & Magdalenian \\
Ly-393 & Bone & Solutré (3) & Square P16 & $12,580 \pm 250$ & Magdalenian \\
Ly-560 & Bone & Solutré (3) & Boring B, Level 6 & $30,400 \pm 0$ & Magdalenian \\
Ly-561 & Bone & Solutré (3) & Boring B, Level 6 & $23,200 \pm 700$ & Perigordian \\
Ly-562 & Bone & Solutré (3) & Boring Terre Seve & $21,600 \pm 700$ & Perigordian \\
Ly-1530 & Bone & Solutré (3) & -1.65 to $-1.70 \mathrm{~m}$ & $13,680 \pm 240$ & Magdalenian \\
Ly-1531 & Bone & Solutré (3) & -1.70 to $-1.75 \mathrm{~m}$ & $13,710 \pm 230$ & Magdalenian \\
Ly-1532 & Bone & Solutré (3) & -1.80 to $-1.90 \mathrm{~m}$ & $14,360 \pm 280$ & Magdalenian \\
Ly-1533 & Bone & Solutré (3) & -2.40 to $-2.50 \mathrm{~m}$ & $19,590 \pm 280$ & Solutrean \\
Ly-1534 & Bone & Solutré (3) & -2.10 to $-2.50 \mathrm{~m}$ & $17,310 \pm 470$ & Solutrean \\
Ly-309 & Charred bone & Vignes ChateauBeau(4) & Hearth & $24,150 \pm 550$ & Perigordian \\
Ly-310 & Charred bone & Vignes ChateauBeau(4) & Hearth & $21,100 \pm 1300$ & Perigordian
\end{tabular}


TABLE 2. (Continued)

\begin{tabular}{|c|c|c|c|c|c|}
\hline Lab no. & Material & Site (no. in Fig. 3) & Layer / Level & $\begin{array}{c}{ }^{14} \mathrm{C} \text { age } \\
\text { (yr BP) }\end{array}$ & Culture \\
\hline$\overline{\mathrm{Ly}-311}$ & Bone & Vignes ChateauBeau(4) & Hearth & $22,900 \pm 600$ & Perigordian \\
\hline Ly-2150 & Charred bone & Goutte Roffat (5) & Ashy level & $10,860 \pm 210$ & Magdalenian \\
\hline Ly-3092 & Charred bone & Goutte Roffat (5) & Level 1 & $13,530 \pm 260$ & Magdalenian \\
\hline Ly-3093 & Charred bone & Goutte Roffat(5) & Level $2 a$ & $12,720 \pm 180$ & Magdalenian \\
\hline Ly-3094 & Charred bone & Goutte Roffat (5) & Level 2b & $12,420 \pm 320$ & Magdalenian \\
\hline Ly-3095 & Charred bone & Goutte Roffat (5) & Level 2c & $12,090 \pm 170$ & Magdalenian \\
\hline Ly-3096 & Charred bone & Goutte Roffat (5) & Level 3, Pit 1 & $11,940 \pm 280$ & Magdalenian \\
\hline Ly-3097 & Charred bone & Goutte Roffat (5) & Level 3, Hearth & $12,150 \pm 200$ & Magdalenian \\
\hline Ly-3098 & Charred bone & Goutte Roffat (5) & Level 3, Pit 2 & $12,330 \pm 300$ & Magdalenian \\
\hline Ly-2152 & Charred bone & Vigne Brun (6) & Surface & $16,180 \pm 250$ & Magdalenian \\
\hline Ly-2151 & Charred bone & Vigne Brun (6) & Hearth & $19,500 \pm 480$ & Perigordian \\
\hline Ly-2153 & Charred bone & Vigne Brun (6) & Hearth & $20,840 \pm 390$ & Perigordian \\
\hline Ly-2637 & Charred bone & Vigne Brun (6) & Hearth 010 & $23,450 \pm 690$ & Perigordian \\
\hline Ly-2638 & Charred bone & Vlgne Brun (6) & Hearth & $21,580 \pm 600$ & Perigordian \\
\hline Ly-2639 & Charred bone & Vigne Brun (6) & Hearth 016 & $23,230 \pm 760$ & Perigordian \\
\hline Ly-2640 & Charred bone & Vigne Brun(6) & Hearth & $23,500 \pm 1000$ & Perigordian \\
\hline Ly-391a & Charred bone & Pré Brun (7) & Hearth & $18,520 \pm 500$ & Perigordian \\
\hline Ly-391b & Charred bone & Pré Brun(7) & Hearth & $24,900 \pm 2000$ & Perigordian \\
\hline Ly-3079 & Bone & Cabones (8) & Lower level & $11,520 \pm 191$ & Magdalenian \\
\hline Ly-2296 & Bone & Cabones (8) & Lower level & $12,620 \pm 250$ & Magdalenian \\
\hline Ly-1863 & Ivory & Mère Clochette (9) & Red level & $25,800 \pm 700$ & Perigordian \\
\hline Ly -440 & Bone & Chaumois Boivin (10) & Level C & $12,040 \pm 270$ & Magdalenian \\
\hline Ly-497 & Bone & Arlay (11) & Level G & $15,320 \pm 370$ & Magdalenian \\
\hline Ly-559 & Bone & Arlay (11) & Level E & $15,770 \pm 390$ & Magdalenian \\
\hline Ly-1509 & Bone & Arlay (11) & Level C & $14,220 \pm 560$ & Magdalenian \\
\hline Ly -1510 & Bone & Arlay (11) & Layer C & $14,820 \pm 370$ & Magdalenian \\
\hline Ly-1535 & Bone & Arlay (11) & Layer C & $14,530 \pm 290$ & Magdalenian \\
\hline Ly-1536 & Bone & Arlay (11) & Layer C & $14,840 \pm 360$ & Magdalenian \\
\hline Ly-1798 & Bone & La Baume (12) & Layer IV & $12,370 \pm 460$ & Magdalenian \\
\hline Ly-1702 & Bone & La Baume (12) & Layer IV & $13,620 \pm 480$ & Magdalenian \\
\hline Ly-1703 & Bone & La Baume (12) & Layer V & $22,430 \pm 500$ & Magdalenian \\
\hline Gif-8717 & Charcoal & Le Colombier (13) & Layer 15 & $11,460 \pm 310$ & Magdalenian \\
\hline Ly-5291 & Charcoal & Le Colombier (13) & Layer 16 & $14,660 \pm 660$ & Magdalenian \\
\hline Ly-5292 & Charcoal & Le Colombier (13) & Layer 17 & $14,480 \pm 360$ & Magdalenian \\
\hline Ly-2339 & Bone & Les Pêcheurs (14) & Surface F10-F11 & $23,880 \pm 750$ & Aurignacian \\
\hline Ly-2342 & Bone & Les Pêcheurs (14) & Level 5 & $24,940 \pm 680$ & Epigraveytian \\
\hline Ly-321 & Charcoal & Les Deux Avens (15) & Level C & $12,320 \pm 600$ & Magdalenian \\
\hline Ly-322 & Bone & Les Deux Avens (15) & Level C & $12,350 \pm 200$ & Magdalenian \\
\hline Ly-1984 & Bone & Oullins (16) & Level D & $20,100 \pm 500$ & Solutrean \\
\hline Ly-1983 & Bone & Oullins (16) & Level 9 & $20,060 \pm 450$ & Solutrean \\
\hline Ly-798 & Bone & Oullins (16) & Level 6 & $19,369 \pm 420$ & Solutrean \\
\hline Ly-799 & Bone & Oullins (16) & Level 7 & $19,710 \pm 400$ & Solutrean \\
\hline Ly -800 & Bone & Ebbou (17) & Layer $\mathrm{C} 1$ & $12,980 \pm 220$ & Magdalenian \\
\hline Ly-847 & Charcoal & La Tête du Lion (18) & Layer $\mathrm{E}$ and $\mathrm{F}$ & $21,650 \pm 800$ & Solutrean \\
\hline Ly-597 & Bone & Chinchon (19) & Layer 15 & $12,000 \pm 420$ & Tardigravettian \\
\hline Ly-541 & Bone & Adaouste(20) & Layer 12 & $12,280 \pm 190$ & Magdalenian \\
\hline Ly -540 & Bone & Adaouste (20) & Layer 17 & $12,760 \pm 250$ & Magdalenian \\
\hline Gif-2994 & Charcoal & Fontbregoua (21) & Layer 70 & $11,200 \pm 150$ & Magdalenian \\
\hline Ly-5558 & Charcoal & Grotte Cosquer (22) & Surface soil & $18,440 \pm 440$ & LatePaleolithic \\
\hline Gif A-92348 & Charcoal & Grotte Cosquer (22) & Surface soil & $20,370 \pm 250$ & Late Paleolithic \\
\hline Gif A-92416 & Charcoal & Grotte Cosquer (22) & Painting of horse & $18,840 \pm 240$ & Paleolithic \\
\hline Gif A-92418 & Charcoal & Grotte Cosquer (22) & Painting of feline & $19,200 \pm 220$ & Paleolithic \\
\hline Gif A-92409 & Charcoal & Grotte Cosquer (22) & Painting of hand & $27,110 \pm 390$ & Paleolithic \\
\hline
\end{tabular}


TABLE 2. (Continued)

\begin{tabular}{|c|c|c|c|c|c|}
\hline Lab no. & Material & Site (no. in Fig. 3) & Layer / Level & $\begin{array}{c}{ }^{14} \mathrm{C} \text { age } \\
\text { (yr BP) }\end{array}$ & Culture \\
\hline Ly-357 & Bone & La Croze sur Suran (I) & Hearth & $14,330 \pm 260$ & Magdalenian \\
\hline Ly-434 & Bone & La Croze sur Suran (I) & Hearth & $14,850 \pm 350$ & Magdalenian \\
\hline Ly -433 & Bone & La Colombière (II) & Level D & $13390 \pm 300$ & Magdalenian \\
\hline L-177 & Charcoal & La Colombière (II) & Hearth & $14,150 \pm 450$ & Magdalenian \\
\hline Ly-16 & Charcoal & Les Romains (III) & Layer III & $14,380 \pm 380$ & Magdalenian \\
\hline Ly-356 & Bone & Les Romains (III) & Level III & $12,980 \pm 240$ & Magdalenian \\
\hline MC-1275 & Shells & Les Romains (III) & Level IIb & $12,540 \pm 400$ & Magdalenian \\
\hline MC-1276 & Shells & Les Romains (III) & Level III & $12,540 \pm 230$ & Magdalenian \\
\hline ETH-3937 & Bone & Etrembieres (IV) & Soil of habitation & $12,300 \pm 130$ & Magdalenian \\
\hline B-3787 & Bone & Etrembieres (IV) & Soil of habitation & $12,310 \pm 140$ & Magdalenien \\
\hline Ly-453 & Bone & Douattes (V) & Level B & $10,680 \pm 450$ & Magdalenian \\
\hline Ly-435 & Bone & Douattes (V) & Level 7 & $12,480 \pm 260$ & Magdalenian \\
\hline $0 \times A-538$ & Bone & Bange (VI) & Layer $\mathrm{G}$ & $12,080 \pm 180$ & Magdalenian \\
\hline OxA-540 & Bone & Bange (VI) & Layer $\mathrm{G}$ & $12,200 \pm 160$ & Magdalenian \\
\hline Ly-3640 & Bone & Bange (VI) & Layer $\mathrm{G}$ & $11,680 \pm 190$ & Magdalenian \\
\hline Ly -390 & Charcoal & Saint Thibaud II (VII) & Hearth & $13,300 \pm 280$ & Magdalenian \\
\hline Ly -925 & Bone & Saint Thibaud II (VII) & Layer 3 & $12,400 \pm 240$ & Magdalenian \\
\hline Ly -926 & Charcoal & Saint Thibaud II (VII) & Layer 3 & $13,280 \pm 290$ & Magdalenian \\
\hline Ly -625 & Charcoal & Saint Thibaud II (VII) & Layer Theta & $10,470 \pm 200$ & Magdalenian \\
\hline Ly -692 & Charcoal & Saint Thibaud II (VII) & Layer Theta & $11,590 \pm 330$ & Magdalenian \\
\hline Ly-693 & Charcoal & Saint Thibaud II (VII) & Layer Theta & $11,630 \pm 240$ & Magdalenian \\
\hline Ly -828 & Charcoal & Saint Thibaud II (VII) & Layer 3 & $12,470 \pm 200$ & Magdalenian \\
\hline Ly-829 & Charcoal & Saint Thibaud II (VII) & Layer $9 b$ & $12,720 \pm 230$ & Magdalenian \\
\hline Ly -830 & Charcoal & Saint Thibaud II (VII) & Layer Lambda & $13,070 \pm 210$ & Magdalenian \\
\hline Ly-2911 & Bone & La Fru (VIII) & Layer 2 & $12,690 \pm 380$ & Magdalenian \\
\hline Ly-431 & Bone & Le Calvaire (IX) & Layer 3 & $12,970 \pm 300$ & Magdalenian \\
\hline Ly -432 & Bone & Le Calvaire (IX) & Layer4 & $13,450 \pm 300$ & Magdalenian \\
\hline
\end{tabular}

Chronological distribution of the sites is also irregular. Figure 4 shows the duration of ${ }^{14} \mathrm{C}$-dated settlements of the mountain region, compared with the duration of all the dated sites in the SaôneRhône basin from the south of Burgundy to the Mediterranean coast. It is clear that, before $14.5 \mathrm{ka}$ $\mathrm{BP}$, there is no trace of human presence to the east of the Saône-Rhône Valley (except, on the western fringe of the Jura, the site of Arlay, with its peculiar à navette Magdalenian industry found in rare sites from western France to Poland (Allain et al. 1985), dated from $15.5 \mathrm{ka} \mathrm{BP}$ ). Nor is there a lithic remain prior to the Middle Magdalenian. We sometimes find redeposited Middle Paleolithic material, but never any for the Early or Upper Paleolithic (Aurignacian, Perigordian, Solutrean). On the other hand, a series of settlements or of decorated grottoes from the Perigordian and the Solutrean, in Burgundy (Solutré), Lyonnais (Villerest), Vivarais (Les Pêcheurs) or coastal Provence (Cosquer Grotto) has been found (Fig. 4). The contrast between east and west of the Rhône basin is striking.

The dates of the last retreat remain ambiguous, but it had probably begun as early as $15 \mathrm{ka}$ BP for the whole western Alps. As the first inhabitants of the mountains seem to be contemporaneous with the beginning of the Bølling ( $c a .13 .3 \mathrm{ka} \mathrm{BP}$ ), a long interval ( $c a .2 \mathrm{ka}$ ) elapsed between the ice retreat and this first human migration.

The irregular distribution of the sites is not the sole proof of this delay in settlement; the general outline and conditions of fill of certain sites also lend supportive evidence for the time of occupation. The site of Saint-Thibaud de Couz, at an elevation of $550 \mathrm{~m}$, at the foot of the Epine massif near Chambéry, is a good example of delayed settlement (Bintz 1994). Although the site is not directly implanted on glacial material, it is in direct relation to the former glacier. Figure 5 shows the various 


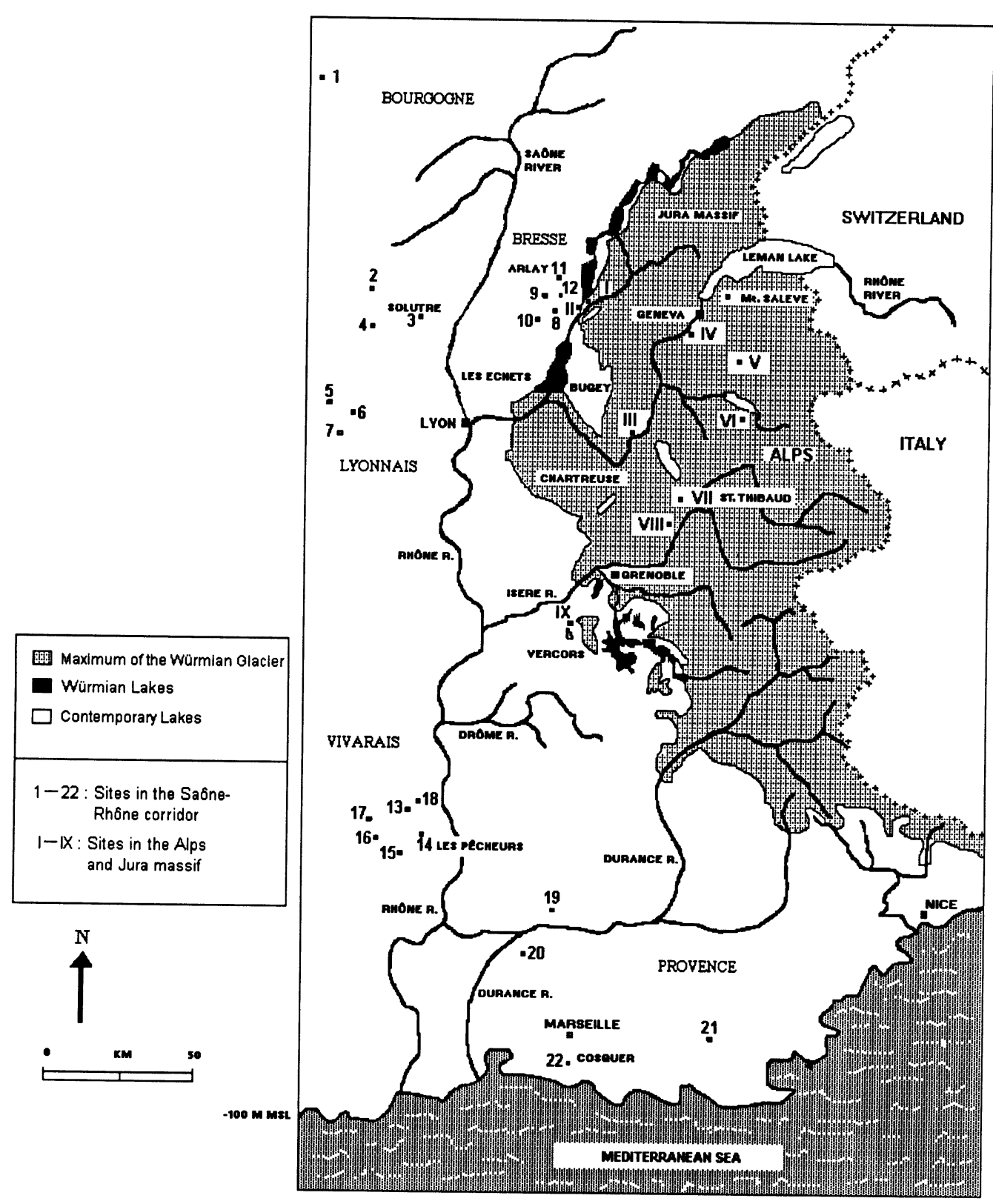

Fig. 3. Location of the Upper Paleolithic sites from the Jura Massif, French Alps and the Saône-Rhône Valley

stages of the development of a site. Although the precise duration between Phase 2 (retreat of the glacier) and Phase 6 (human settlement) cannot be calculated, one may assume it was a very long time, and the glacial front must have been quite remote by the time of settlement. Galay (1992) used the same reasoning for evaluating the site of Etrembières (Veyrier), which was located directly on glacial till on the mountainside of Mt. Salève near Geneva. The first Magdalenians who resided here must have viewed the same landscape as do present-day Genevans. Thus, either Upper Magdalenian 


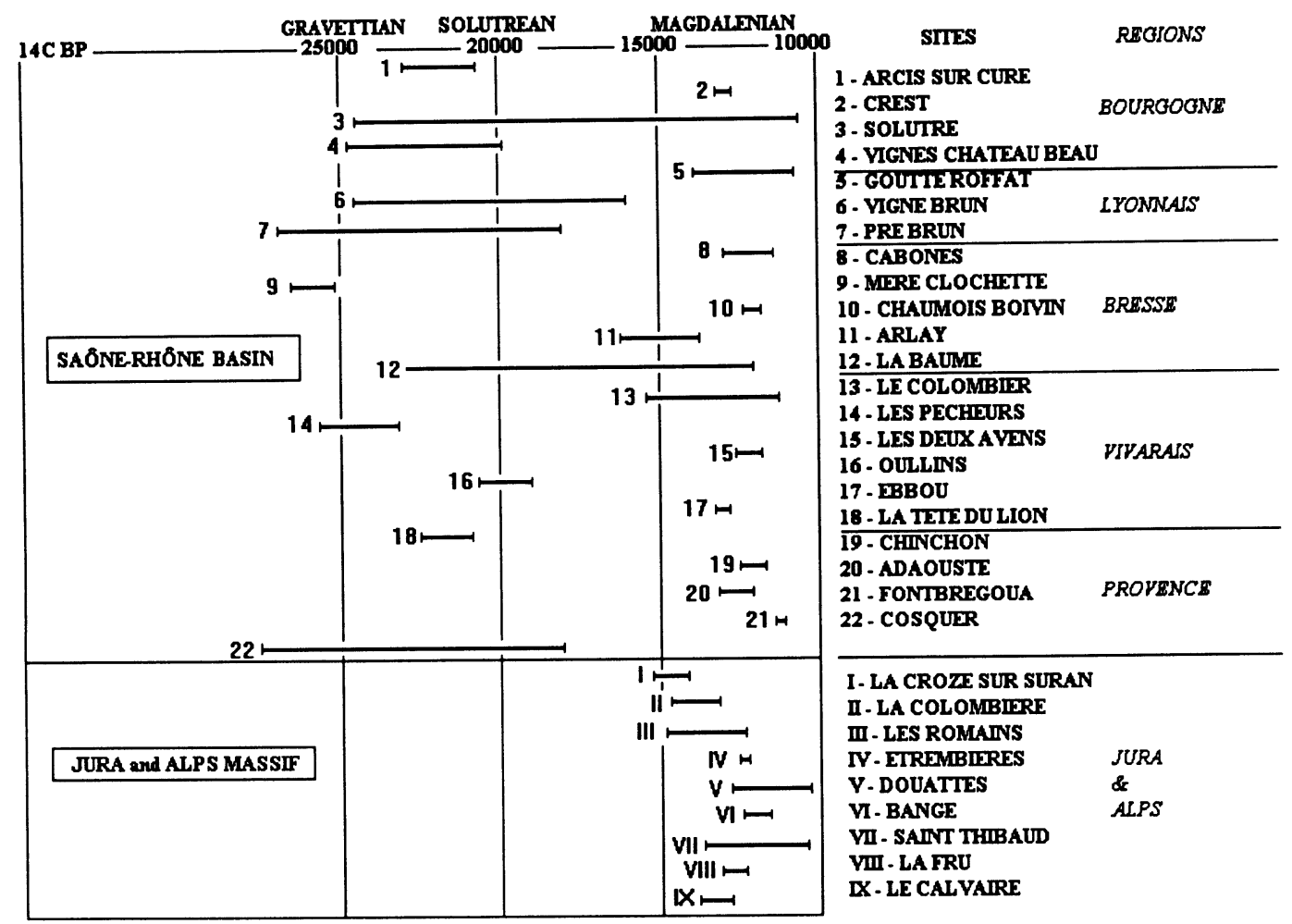

Fig. 4. Duration of human occupation in the sites of the Saône-Rhône basin, the Jura and the French Alps

sites of the French Alps are located where glaciers melted a long time before, or the ${ }^{14} \mathrm{C}$ dates of these sites are too young (12-10 ka BP).

Throughout the pleniglacial and at only $80 \mathrm{~km}$ from the extreme advance of the glacial front, a human population left some sites to the west of the Rhône corridor. The pollen diagram of Les Echets swamp, $10 \mathrm{~km}$ north of Lyon (de Beaulieu et al. 1980) shows that, at this time, large melted patches of sparsely vegetated land covered the piedmont area. Yet, no archaeological sites were found east of the Rhône basin, neither before nor during the last pleniglacial. Further, there is no evidence of human settlement in the mountain zone. Perhaps during the pleniglacial, even after the main glaciers receded (i.e., during most of the Würmian), the deeply eroded valleys dug by the first maximal glacial expansion (at a very early date) remained covered by sheets of stagnant ice. Thus, the landscapes were probably not conducive to habitation. Also, great lakes of melted ice with steep banks in U-shaped valleys could have rendered the intra-Alpine massifs inaccessible (Fig. 6).

Deglaciation spread mainly throughout the northern French Alps (Fig. 1). As for the southern Alps, that is, those south of the Drôme and upper Durance Rivers, the massifs and valleys were not glaciated; the only important glacier was that of the Durance, supplied at a high altitude by the Pelvoux massif. Thus, the southern Alps were cleared and accessible throughout the Würmian. However, they are totally devoid of Upper Paleolithic sites, except near the Rhône River and the Mediterranean Sea. 

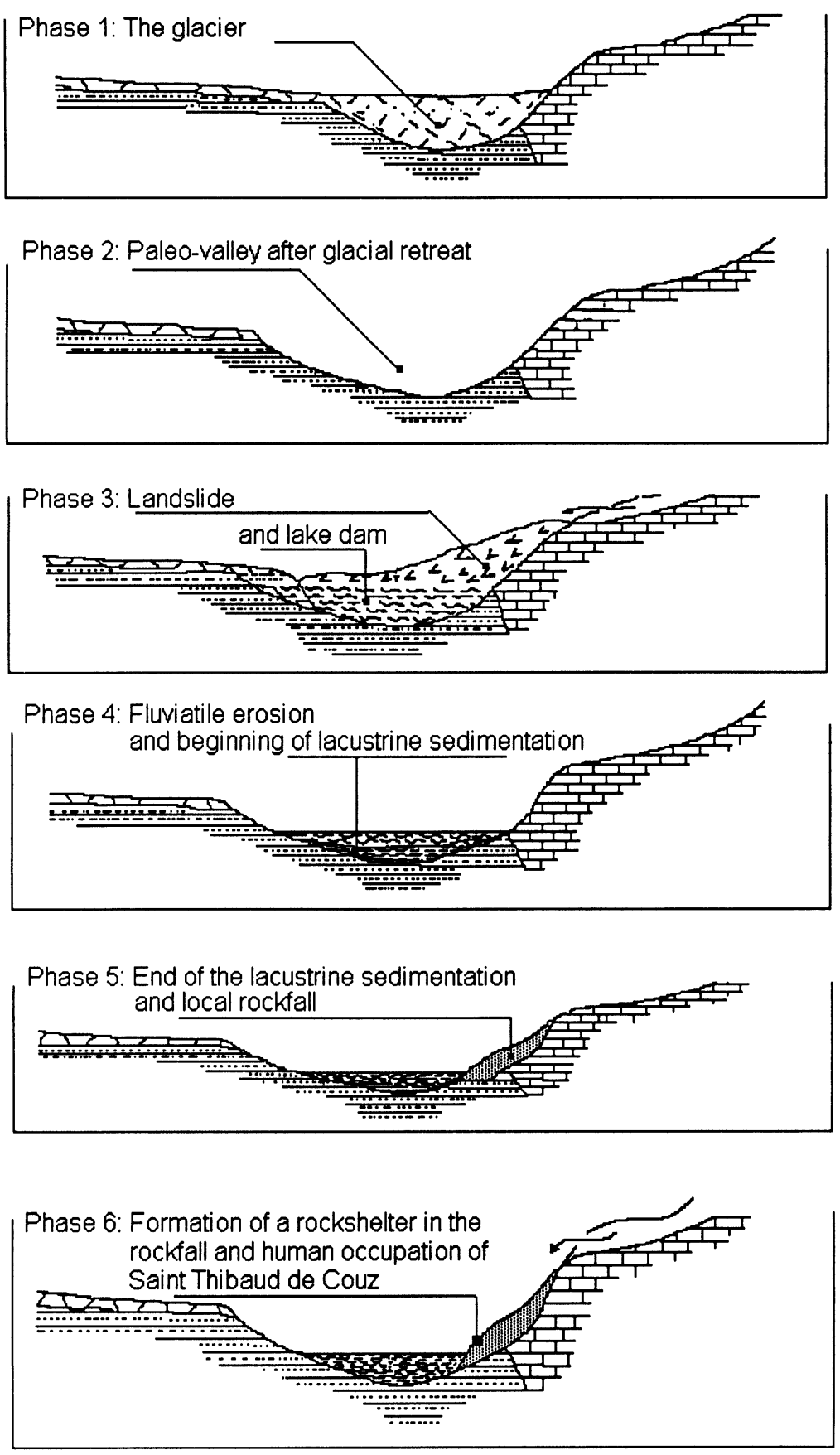

Fig. 5. Assumed phases of land formation around the site of Saint Thibaud de Couz, showing the long transition between glacial retreat and human settlement 


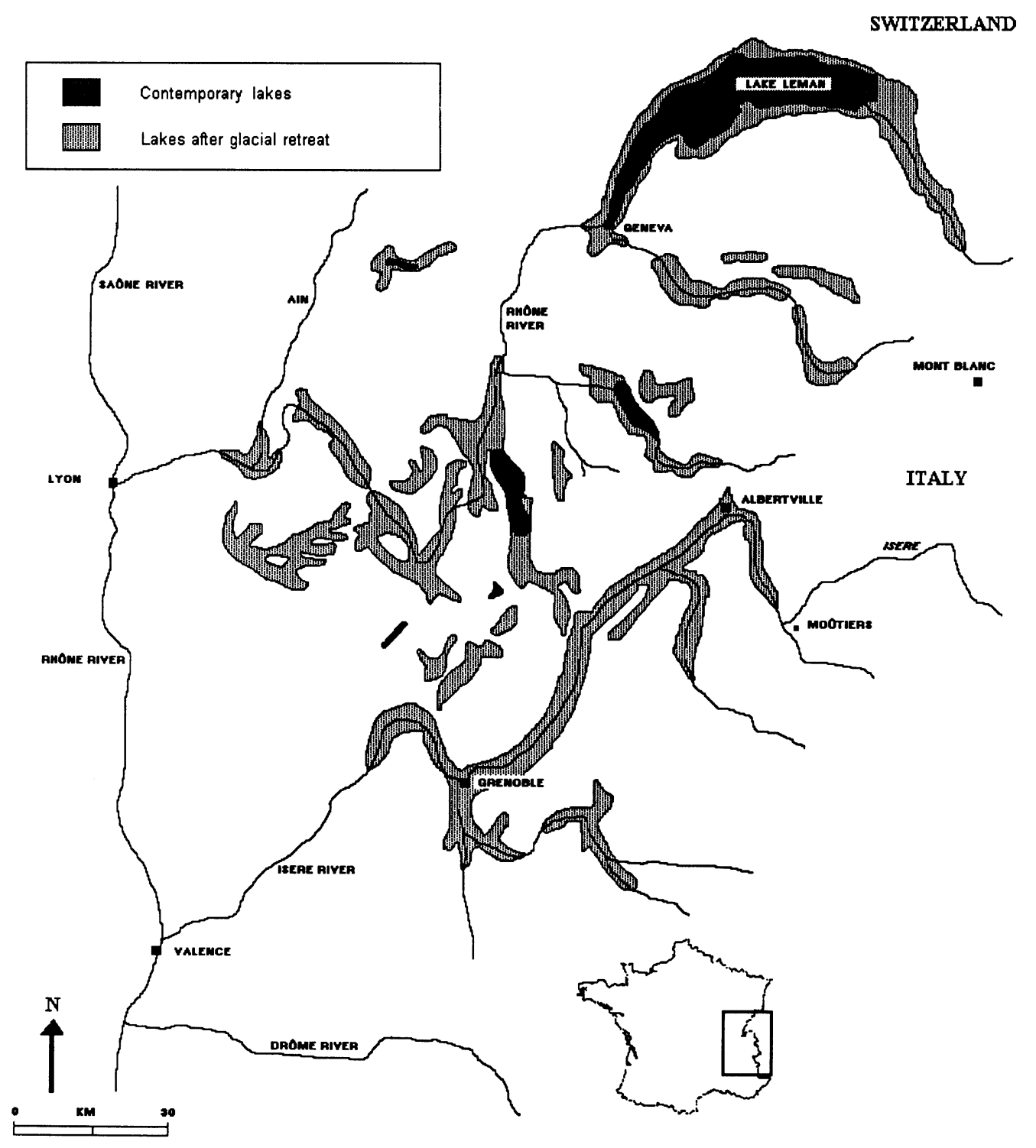

Fig. 6. Lakes in the northern French Alps after the Würmian deglaciation 


\section{CONCLUSION}

Little has been written on the chronology of final deglaciation of the French Alps due to the lack of geological and ${ }^{14} \mathrm{C}$ data. However, there seems to be no connection between the first human settlement and the extension of the last glaciation. Indeed, the study of site distribution and glacial deposits shows that, for reasons yet unknown, settlement occurred long after deglaciation, and sites were far distant from the glacial front. More sites will have to be studied before we can understand the motives for population movements toward high elevations and for the apparent non-relation between glaciers and human settlement.

\section{REFERENCES}

Allain, J., Debrosse, R., Kozlowski, J. K. and Rigaud, A. 1985 Le Magdalenien à navettes. Gallia Préhistoire 28: 37-124.

Arn, R. (ms.) 1984 Contribution à l'Etude Stratigraphique du Pléistocène de la Région Lémanique. Ph.D. dissertation, University of Lausanne: $307 \mathrm{p}$.

Bintz, P. 1994 Le site magdalénien de Saint-Thibaud de Couz (Savoie). Gallia-Préhistoire, Supplément 1994, in press.

Blavoux, B. and Brun, A. 1966 Nouvelles données sur les terrains quaternaires de la région lémanique. Comptes Rendus des Séances de l'Académie des Sciences, Paris 262: 2569-2572.

Campy, M. and Richard, H. 1988 Modalités et chronologie de la déglaciation würmienne dans la chaine jurassienne. Association Française pour l'Etude du Quaternaire Bulletin 1988: 8190.

Clerc, J. (ms.) 1988 Recherches Pollenanalytiques sur la Paléoécologie Tardiglaciaire et Holocène du Bas-Dauphiné. Ph.D. dissertation, University of Aix-Marseille III: $179 \mathrm{p}$.

de Beaulieu, J. L., Evin, J., Mandier, P., Monjuvent, G. and Reille, M. 1980 Les Echets: Un marais capital pour l'histoire climatique du Quaternaire rhôdanien. Musée National Histoire Naturelle Bulletin Series B 27: 123-136.

Delibrias, G., Guillier, M. T. and Labeyrie, J. 1969 Gif natural radiocarbon measurements III. Radiocarbon 11(2): 327-344.

Evin, J., Maréchal, J. and Marien, G. 1985 Lyon natural radiocarbon measurements X. Radiocarbon 27(2B): 386-454.

Evin, J., Marien, G. and Pachiaudi, C. 1976 Lyon natural radiocarbon measurements VI. Radiocarbon 18(1): $60-88$.

Galay, A. 1992 Les chasseurs de rennes de Veyrier pouvaient-ils contempler le glacier du Rhône? In Le Grand Livre du Saleve. Geneva, Switzerland, Tribune Press: $24-47$.

Hannss, C. 1982 Spätpelistozäne bis postglaziale Talverschüttungs- und Vergletscherungsphasen im Bereich des Sillon Alpin des französischen Nordalpen. Mitteilungen der Kommission für Quartärforschung der Österreichischen Akademie der Wissenschaften 4: $213 \mathrm{p}$.

Jorda, M., Rosique, T. and Evin, J. 1995 Premières datations au ${ }^{14} \mathrm{C}$ de dépots morainiques würmiens dans la vallée de la Durance. Comptes Rendus des Séances de l'Académie des Sciences, Paris, Series II 318, in press.

Mandier, P. (ms.) 1984 Le Relief de la Moyenne Vallée du Rhône au Tertiaire et au Quaternaire; Essai de Synthèse Paléogéographique. Ph.D. dissertation, University of Lyon II: $1025 \mathrm{p}$.

1988 Les problèmes chronologiques posés par les phases de la glaciation würmienne dans la moyenne vallée du Rhône. Association Française pour l'Etude du Quaternaire Bulletin 1988: 123-128.

Mandier, P. and Piegay, H. 1991 Eléments nouveaux sur les phases de récession du glacier rhôdanien dans la region des Terres Froides septentrionales autour de Morestel. Laboratoire Rhôdanien Géomorphologie Bulletin 27-28: $53 \mathrm{p}$.

Monjuvent, G. 1988 La déglaciation rhodanienne entre les moraines internes et le Val du Bourget. Géologie Alpine 64: 61-104.

Monjuvent, G. and Nicoud, G. 1988 Interprétation de la déglaciation rhôdanienne au Würm, des moraines internes à la cuvette lémanique. Association Française pour l'Etude du Quaternaire Bulletin 1988: 129-140. 